\title{
The Steck Site (41WD529), a Titus Phase Settlement in the Lake Fork Creek Drainage Basin, Wood County, Texas
}

Timothy K. Perttula

Heritage Research Center, Stephen F. Austin State University

Bob D. Skiles

Follow this and additional works at: https://scholarworks.sfasu.edu/ita

Part of the American Material Culture Commons, Archaeological Anthropology Commons, Environmental Studies Commons, Other American Studies Commons, Other Arts and Humanities Commons, Other History of Art, Architecture, and Archaeology Commons, and the United States History Commons

Tell us how this article helped you.

This Article is brought to you for free and open access by the Center for Regional Heritage Research at SFA ScholarWorks. It has been accepted for inclusion in Index of Texas Archaeology: Open Access Gray Literature from the Lone Star State by an authorized editor of SFA ScholarWorks. For more information, please contact cdsscholarworks@sfasu.edu. 


\section{The Steck Site (41WD529), a Titus Phase Settlement in the Lake Fork Creek Drainage Basin, Wood County, Texas}

\section{Creative Commons License}

\section{(c) (1) (8)}

This work is licensed under a Creative Commons Attribution-NonCommercial 4.0 International License 


\title{
The Steck Site (41WD529), a Titus Phase Settlement in the Lake Fork Creek Drainage Basin, Wood County, Texas
}

\author{
Timothy K. Perttula and Bob D. Skiles
}

\section{INTRODUCTION AND SETTING}

The Steck site (41WD529) is a 15th to early 16th century A.D. Caddo settlement situated in the far western margins of the modern Pineywoods of East Texas, in the upper Sabine River basin in Wood County (Figure 1). The site is specifically situated in the uplands more than $12 \mathrm{~m}$ above the Dry Creek floodplain, in the upper part of the Lake Fork Creek drainage basin. Two natural springs emerge from the Queen City Eocene formation immediately below the site.

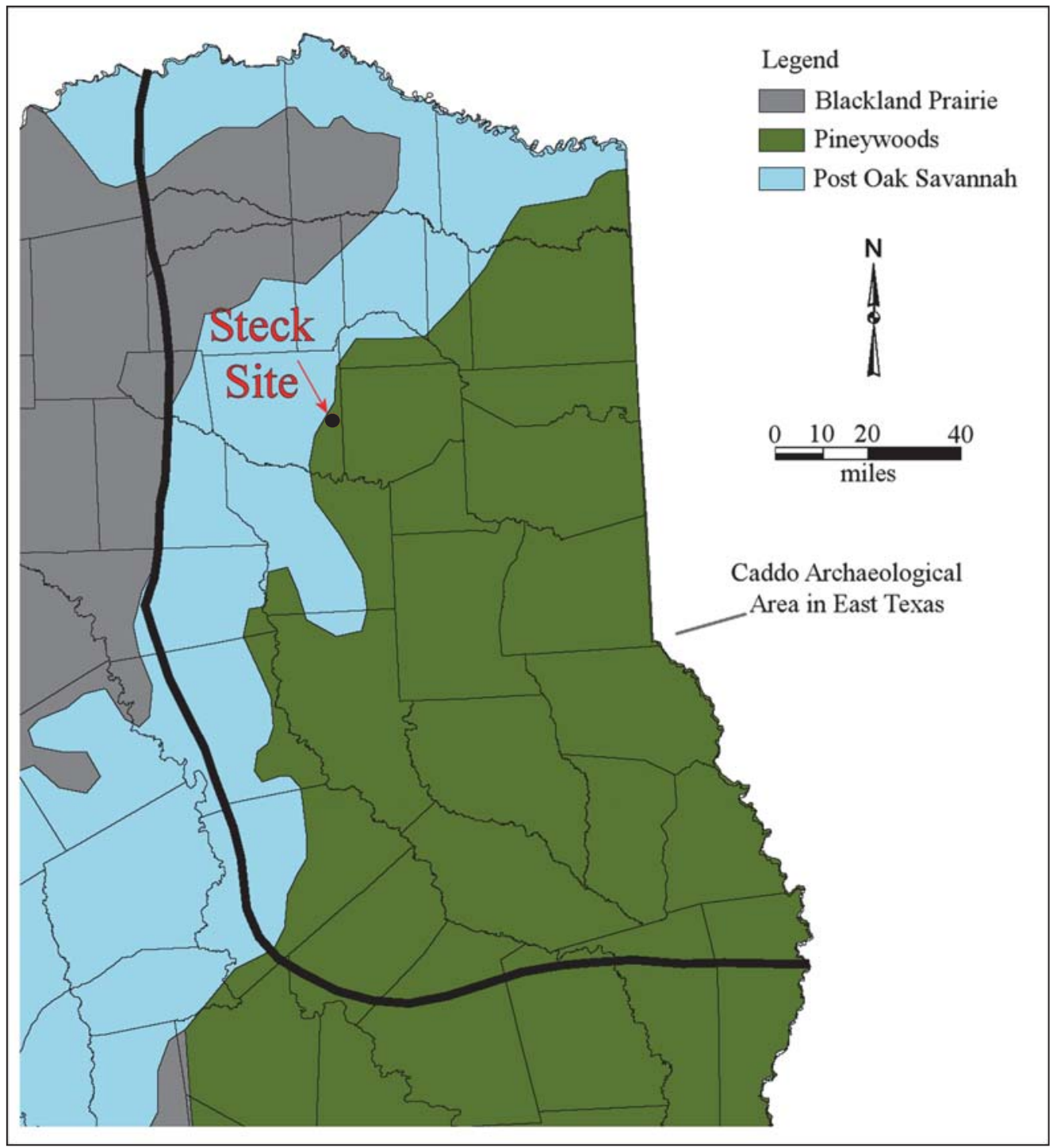

Figure 1. Location of the Steck site in East Texas. 
There are two midden deposits at the Steck site, as well as evidence for structures arranged around an open plaza in a small community. The archaeological investigations reported on in this article took place in 1976 in a ca. 9 m diameter trash midden deposit along the edge of the upland landform; the trash midden was ca. $30 \mathrm{~cm}$ in thickness. Available notes and analysis records have been used to reconstruct what was accomplished at the site and the kind and range of recovered artifacts.

\section{ARCHAEOLOGICAL INVESTIGATIONS}

The landowner of the Steck site had at one time built a driveway through the midden deposits. When it was learned by an archaeological crew from Southern Methodist University (SMU) working on sites in the nearby Lake Fork Reservoir (see Bruseth et al. 1977; Bruseth and Perttula 1980, 1981) that the landowner was planning on removing more of the midden by widening a driveway to a trailer house, limited excavations were undertaken on the east side of the driveway in the trash midden. This work was done in June to August 1976 (Hockensmith n.d.).

A total of $18 \mathrm{~m}^{2}$ was excavated in the midden (Figure 2). Excavations proceeded in $5 \mathrm{~cm}$ arbitrary levels in $1 \times 1 \mathrm{~m}$ units, and approximately $6000-9000 \mathrm{cc}$ from each level were removed for flotation analysis $(\mathrm{n}=30$ flotation samples). Considerable amounts of preserved plant and animal remains were recovered in the midden (see below).

Wood charcoal recovered from Unit $10(15-20 \mathrm{~cm}$ bs $)$ in the midden was submitted to the University of Texas Radiocarbon Laboratory by James E. Bruseth at SMU. The conventional radiocarbon age of the sample is A.D. $1470 \pm 90$ (Tx-3473). The IntCal09 2 sigma calibration of the sample has age ranges of A.D. 1296-1530 (0.79 probability) and A.D. 1540-1635 (0.17). The median calibrated age is A.D. 1439.

\section{MATERIAL CULTURE REMAINS}

\section{Ceramic Artifacts}

The midden at the Steck site contained a high density of ceramic sherds from broken and discarded plain ware, fine ware, and utility ware vessels. The mean density of the sherds in the midden is approximately 180 per $\mathrm{m}^{2}$. There are 2476 plain sherds and 937 decorated sherds in the excavated midden sample. The plain to decorated sherd ratio is 2.64 . The vessels are almost exclusively grog-tempered, as 99.2 percent of the decorated sherds are grog-tempered and only 0.8 percent are bone-tempered. In the plain wares, 99.8 percent of the sherds are grog-tempered and 0.2 percent have bone temper.

\section{Ceramic Sherds}

The plain wares include 103 rims, 2291 body sherds, and 72 base sherds. The rims are from jars, carinated bowls, and bottles $(n=3)$. Sherd cores are primarily dark gray to black, with oxidized surfaces, indicating they are from vessels fired in a reducing environment, then cooled in the open air. Many of the sherds are from well smoothed to burnished vessels.

The decorated sherds from the Steck site are dominated by sherds from engraved and red slipped fine ware vessels (57.8 percent) (Table 1); they include sherds from carinated bowls, compound bowls, and bottles. Utility ware jar sherds comprise 42.2 percent of the decorated sherds from the site, primarily from neck banded, appliqued, and brushed vessels. 


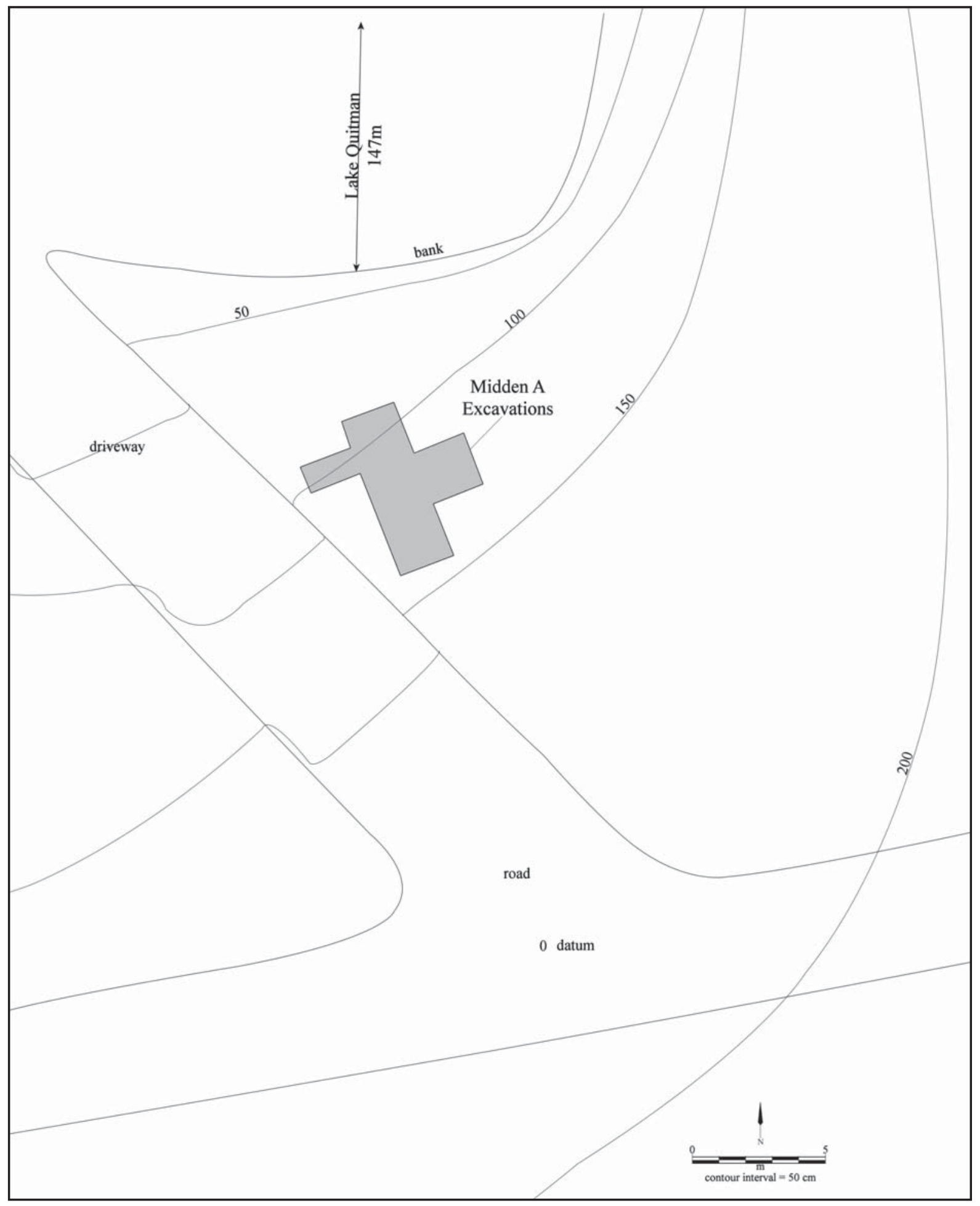

Figure 2. Map of excavations at the Steck site. 
Table 1. Decorated sherds from the Steck site.

\begin{tabular}{lrr}
\hline Decorative Method & No. & Percent \\
\hline Fine ware & & \\
& 388 & 41.4 \\
Engraved & 154 & 16.4 \\
Red Slipped & & \\
Utility ware & & \\
Appliqued & 104 & 11.1 \\
Brushed & 81 & 8.7 \\
Brushed-Appliqued & 2 & 0.2 \\
Brushed-Punctated & 4 & 0.4 \\
Corn Cob Impressed & 5 & 0.5 \\
Incised & 37 & 4.0 \\
Incised-Punctated & 1 & 0.1 \\
Neck Banded & 134 & 14.3 \\
Fingernail Punctated & 26 & 2.8 \\
Tool Punctated & 2 & 0.2 \\
\hline Totals & 937 & 100.0 \\
\hline
\end{tabular}

The engraved sherds from the Steck site are primarily from Ripley Engraved carinated bowls, although there are also a few sherds from at least one Ripley Engraved bottle. There are also sherds from a probable Avery Engraved compound bowl made with shell temper, four sherds from a Taylor Engraved bottle, and sherds from a shouldered Simms Engraved bowl with a sharply upturned lip. The probable Avery Engraved vessel was likely made by a McCurtain phase Caddo group on the Red River, and traded to the occupants of the Steck site.

About 26 percent of the engraved sherds have either a red $(n=47)$ or white $(n=56)$ clay pigment that had been rubbed into the engraved decoration. A number of the engraved sherds are also from red-slipped vessels ( $n=69,17.8$ percent of the engraved sherds). The many red slipped sherds are from bowls and bottles, including 11 bowl rims and four bottle necks.

The neck banded sherds, including 38 rims, are from La Rue Neck Banded vessels. Neck banded utility wares are relatively common in upper Sabine River basin Titus phase sites (see Bruseth and Perttula 1981; Perttula 2005; Perttula et al. 1993). One neck banded sherd has more of a corrugated effect, and Andrew Lindsay (archaeologist at Northern Arizona University) identified it as a sherd from an eastern Arizona Homolovi Corrugated vessel (1977 personal communication to Bob D. Skiles), and thus indicative of contact and trade between a western Pueblo group and an ancestral upper Sabine River basin Caddo group.

The appliqued sherds are from both Harleton Appliqued and McKinney Plain jars. The latter $(\mathrm{n}=15$ sherds) have appliqued fillets and/or nodes that quadrate the rim of large jars. The appliqued elements typically consist of two appliqued fillets arranged like inverted parentheses with one or two appliqued nodes between them; these are arranged from just below the lip to halfway to the rim/body juncture. Other appliqued sherds have vertically oriented appliqued filets; a few sherds have nodes at the end of the fillets. 
The brushed sherds are body sherds from utility ware jars, probably from Harleton Appliqued, Karnack Brushed-Incised, Maydelle Incised, or Bullard Brushed vessels; the brushing was likely oriented vertically on the vessel body. The brushed-appliqued sherds have vertical brushing marks on either side of a vertical appliqued fillet. The incised sherds are from Maydelle Incised vessels. The punctated sherds have horizontal rows of punctations on the rim made either with a fingernail or a tool (i.e., a pointed stick), and are from Mockingbird Punctated jars. One rim has only a single row of punctations at the rim-body juncture. Five sherds have corn cob impressions (i.e., where a corn cob was rolled over the wet surface of an unfired jar). These are from a Anglin Corn Cob Impressed vessel, a new upper Sabine River basin Titus phase ceramic type (see Perttula and Selden, this volume).

\section{Ceramic Pipe Sherds}

The few ceramic pipe sherds from the Steck site are from the bowl of various elbow pipes (Figure 3ah). The bowls have polished exterior surfaces, and either have no visible temper or are tempered with finely crushed grog. The bowls have flattened (Figure 3a, d, f), rounded (Figure 3b), or thinned (Figure 3h) lips.

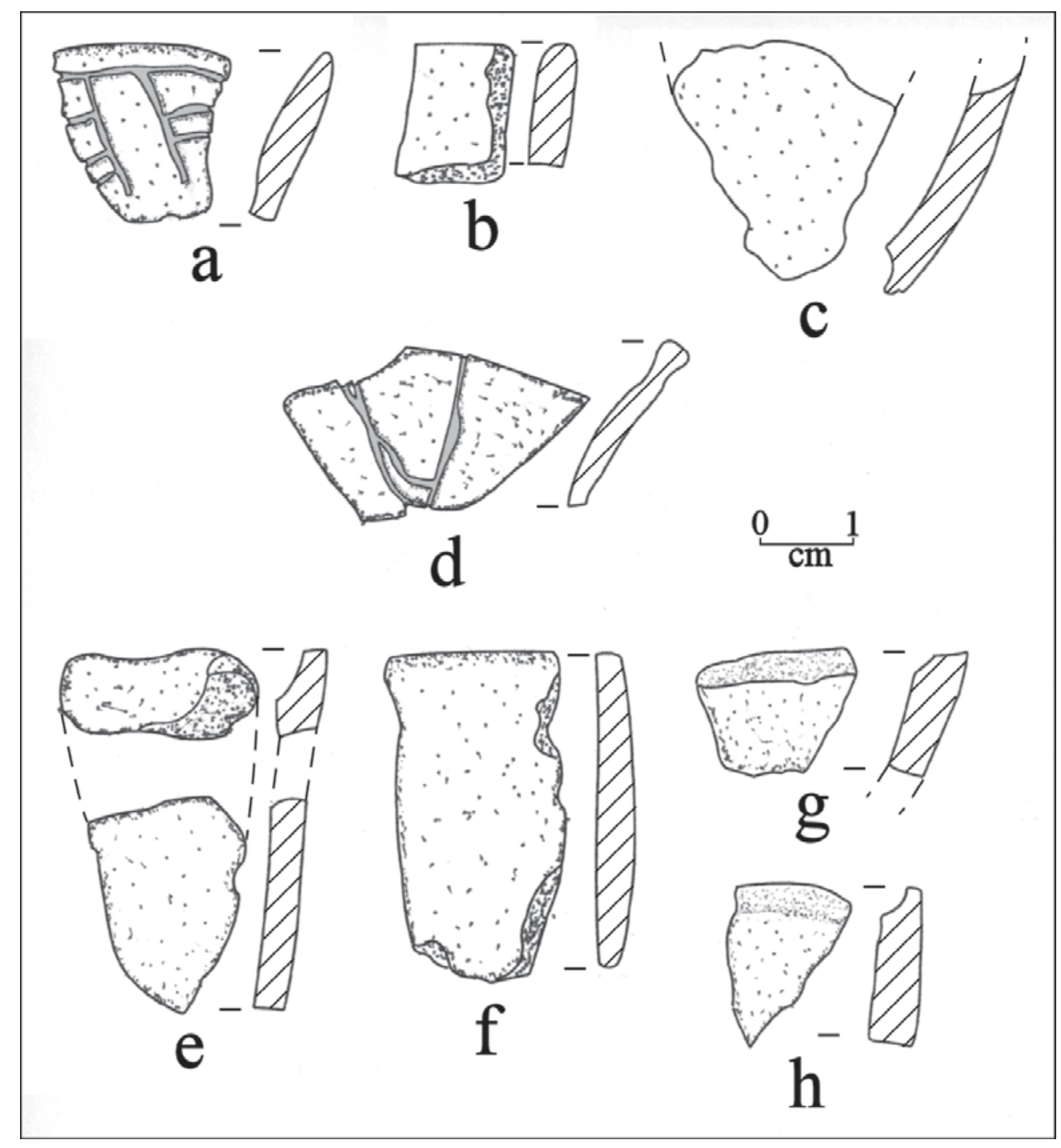

Figure 3. Ceramic pipe sherds from the Steck site. 
One of the pipe bowls has a horizontal engraved line below the lip as well as vertical panels with sets of horizontal engraved lines (see Figure 3a). The bowl also has a red slip and a white clay pigment rubbed in the engraved lines.

\section{Lithic Artifacts}

A small sample of projectile points are in the Steck site assemblage: six arrow points, seven dart points, and a dart point preform (Figure 4). The arrow points (Figure 4a-f) are indicative of a Late Caddo, Titus phase occupation, and suggest that the midden deposits may have accumulated over several generations in the 15th and 16th centuries A.D.
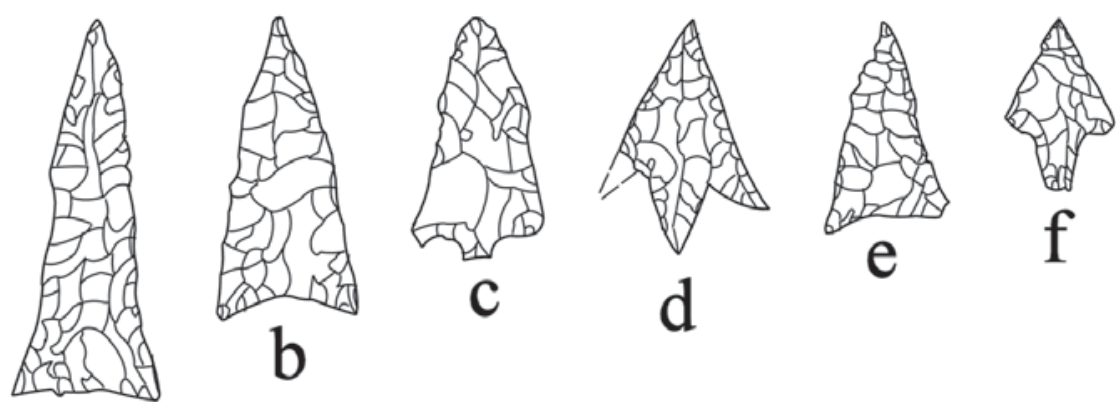

a

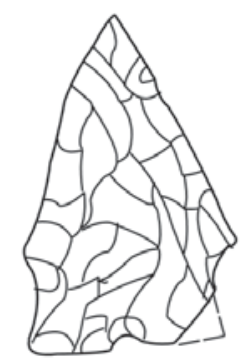

$\mathrm{g}$

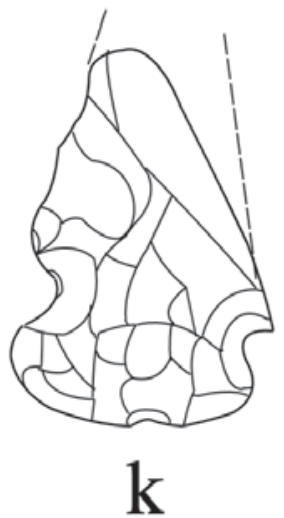

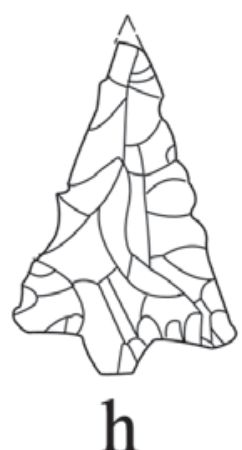

$\mathrm{h}$
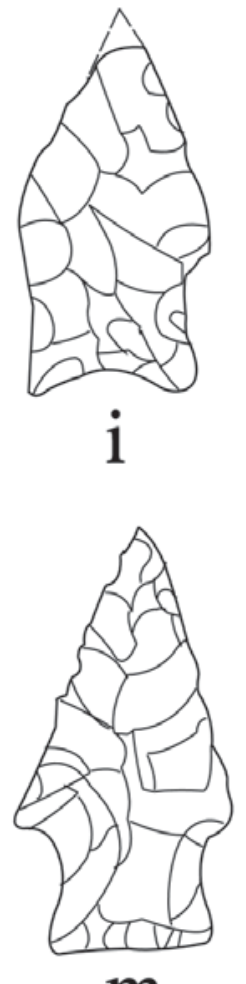

$\mathrm{m}$
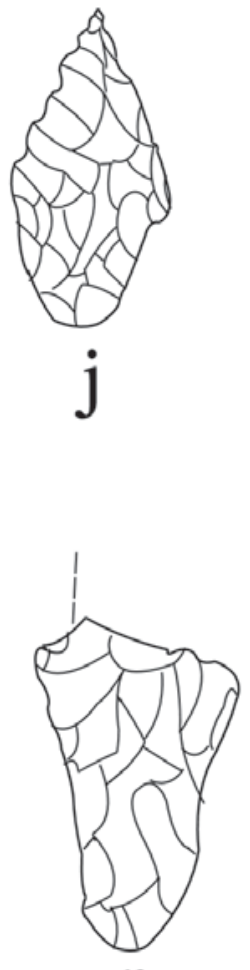

n

Figure 4. Projectile points from the Steck site: a, Talco; b, e, Maud; c, Bassett; d, f, Perdiz; g, Edgewood; h, dart point preform; i, m, Yarbrough; j, 1, Gary; k, Trinity; n, Wells. 
The dart points are evidence that the upland landform was periodically used during the Late Archaic (ca. 5000-2500 years B.P.) and Woodland (ca. 2500-1150 years B.P.) periods. The Late Archaic points include Yarbrough $(n=2)$, Trinity $(n=1)$, and Wells $(n=1)$ specimens (see Figure 4i, $k, m-n)$, while the Woodland period dart points are represented by Gary $(n=2)$ and Edgewood $(n=1)$ types (see Figure $4 \mathrm{~g}, \mathrm{j}-1)$. The one dart point preform (see Figure $4 \mathrm{~h}$ ) may be related to Gary point manufacture.

\section{PLANT AND ANIMAL REMAINS}

Plant remains recovered in the trash midden deposits included $87.7 \mathrm{~g}$ of wood charcoal and $23.9 \mathrm{~g}$ of charred plant food remains (Perttula et al. 1982:Table 5). This included hickory nut shells (11.1 g, Carya sp.), acorn nut meat (2.6 g, Quercus sp.), maize ( $8.8 \mathrm{~g}, 326$ cupules and 51 kernels, Zea mays), common bean (3.0 g, Phaseolus vulgaris), Cucurbitae stem $(0.1 \mathrm{~g})$, and 11 seeds $(0.3 \mathrm{~g})$ of grape (Vitis sp.), spurge (Euphorbia sp.), buttonweed (Diodia teres), and an unidentified grass seed. Hickory nuts and maize were present in 100 percent of the flotation samples, 73 percent of the flotation samples had acorn nut meats, and 20 percent had cultivated bean remains. In general, the plant food remains from the Steck midden indicate that cultivated plants formed a major part of the subsistence strategy of the Caddo peoples living there.

The faunal remains from the trash midden include 588 identified specimens (NISP) from a minimum number of 25 individuals (MNI) (Perttula et al. 1982:Table 4). Turkey, deer, and dog (at least two individuals are from burials) comprise 83 percent of the NISP and 44 percent of the MNI. Mammals account for 64 percent of the MNI; birds 16 percent; reptiles 8 percent; amphibians 8 percent, and 4 percent fish. The deer included a subadult and three other deer aged between 1.5-3 years of age at death. Woodland and forestedge habitats in the uplands and in the Dry Creek valley were exploited for deer and turkey, as they were the dominant species at the Steck site during the Titus phase occupation.

\section{SUMMARY AND CONCLUSIONS}

The Steck site (41WD529) was a well preserved Late Caddo period, Titus phase component in the Lake Fork Creek basin in the Pineywoods in the upper Sabine River drainage; several dart points found there also indicate that the site was sporadically used by Late Archaic and Woodland period hunter-gatherers between ca. 5000-1150 years ago. The ancestral Caddo component included both habitation deposits and trash midden deposits. Because one of the middens at the site was to be destroyed, a volunteer crew from the SMU Lake Fork Reservoir project conducted excavations in 1976 in this trash midden. The purpose was to recover material culture remains from the site from well-controlled excavation contexts, as well as to recover samples of plant and animal remains that were apparently well preserved and abundant in the trash midden. The one radiocarbon date from the trash midden, along with the range in decorative styles and types of recovered utility ware and fine ware ceramic sherds and arrow points, suggest that the Steck site may have been occupied in the 15th and 16th centuries A.D. by a Caddo farming community.

\section{ACKNOWLEDGMENTS}

We thank the Steck family for their willingness to permit excavations at the site before it was destroyed. We also thank the various people from the Lake Fork Reservoir project crew that worked on the site, including Charles Hockensmith, Jim Bruseth, Cathy Crane, Kimball Banks, Cathy Banks, Beverly Mitchem, Carol Carter, Karen Forsythe, Jim Rickards, Pamela McCowan, and Toni Moore, as well as Billy Roberts (Holloway Construction Company), and Kevin and Kyle Smilie. Lance Trask prepared the figures for this article. 


\section{REFERENCES CITED}

Bruseth, J. E. and T. K. Perttula

1980 Archaeological Research at Lake Fork Reservoir: Excavations at the Howle Site and Site Testing. Archaeology Research Program, Southern Methodist University, Dallas.

1981 Prehistoric Settlement Patterns at Lake Fork Reservoir. Texas Antiquities Permit Series, Report No. 2. Texas Antiquities Committee and Southern Methodist University, Austin and Dallas.

Bruseth, J. E., J. T. Bagot, K. M. Banks, and M. A. McKinley

1977 Archaeological Research at Lake Fork Reservoir: Site Inventory and Assessment. Research Report No. 87. Archaeology Research Program, Southern Methodist University, Dallas.

Hockensmith, C.

n.d. The Steck Site Field Notes, June 25, 1976-August 19, 1976. On file with the authors.

Perttula, T. K.

2005 The M. W. Burks Site (41WD52), A Late Caddo Hamlet in Wood County, Texas. Journal of Northeast Texas Archaeology 23:1-27.

Perttula, T. K., C. J. Crane, and J. E. Bruseth 1982 A Consideration of Caddoan Subsistence. Southeastern Archaeology 1(2):89-102.

Perttula, T. K., B. D. Skiles, and B. C. Yates

1993 The Goldsmith Site (41WD208): Investigations of the Titus Phase in the Upper Sabine River Basin, Northeast Texas. Bulletin of the Texas Archeological Society 61:139-191. 